\title{
IDENTIFIKASI KONFLIK MENANTU TERHADAP MERTUA YANG TINGGAL SERUMAH DI KOTA PALANGKA RAYA
}

\author{
Salman $^{1}$, Arini Safitri ${ }^{2}$, Desi Erawati ${ }^{3}$ \\ Prodi Bimbingan dan Konseling Islam, Fakultas Ushuluddin, Adab dan Dakwah IAIN Palangka Raya \\ 3erawati1377@gmail.com
}

\begin{abstract}
ABSTRAK
Dilatarbelakangi dari banyaknya konflik yang timbul ketika anak memutuskan untuk tetap tinggal satu rumah dengan orang tua ketikauu sudah menikah dan membawa serta pasangannya untuk tinggal bersama. Tujuan penelitian ini untuk mengetahui identifikasi sikap menantu terhadap mertua yang tinggal serumah di kota Palangka Raya. Jenis penelitian ini adalah penelitian lapangan dengan pendekatan kualitatif deskriptif fenomenologi. Adapun sumber data dalam penelitian ini ada lima Informan yaitu lima menantu perempuan yang tinggal serumah dengan mertuanya di jalan dr. Murjani. Untuk pengolahan data dengan observasi, wawancara dan dokumentasi, data dianalisis dan disimpulkan atau verifikasi. Adapun hasil penelitian ini menunjukkan bahwa identifikasi konflik pada menantu yang tinggal serumah dengan mertuanya di kota Palangka Raya ditinjau dari konflik intrapersonal, konflik interpersonal dan faktor penyebab konflik. Adapun yang masuk dalam kategori intrapersonal pada unsur pendekatanpenghindaran terjadi pada dua menantu sedangkan yang masuk dalam kategori unsur penghindaranpenghindaran terjadi pada tiga menantu, selanjutnya yang masuk pada katagori interpersonal pada unsur escalation, invalidation, withdrawal and avoidance dan negative interpretation terjadi pada lima menantu yang tinggal serumah dengan mertuanya. Sedangkan Faktor yang melatarbelakangi terjadinya konflik dalam penelitian ini ada lima yaitu, kurangnya komunikasi terlihat pada tiga menantu. Kemudian yang kedua, sikap egosentrisme dalam hal ini ditemukan juga pada tiga menantu. selanjutnya masalah ekonomi yang dialami oleh satu menantu. Berikutnya adanya perbedaan pendapat ditemukan pada kelima menantu dan yang terakhir yaitu salah paham hal ini juga dimiliki oleh kelima menantu.
\end{abstract}

Kata Kunci: Konflik; Menantu Perempuan; Mertua Perempuan; Tinggal Serumah

\begin{abstract}
Background in this research because there are many conflict that appear when a child decide to live in one house with their parents after married and bring their couple to live together. Research objective was to know the conflict identification between daughter in law and mother in law who lived in one house in Dr. Murjani street Palangka Raya.This research was field research with qualitative descriptive approach. While data source in this research were five daughters in law who lived in on house with her mother in law which lived in Dr. Murjani street as informants. Data collection used observation, interview and documentation, then data analyzed and concluded or verification.The result showed that conflict identification on daughter in law who lived in one house with her mother in law at Dr. Murjani street Palangka Raya reviewed from intrapersonal conflict, interpersonal conflict and factors that caused conflict. Approaches-avoidance element that happen on two daughters in law, while avoidanceavoidance element happen on three daughters in law and these two things entered intrapersonal category, while escalation, invalidation, withdrawal and avoidance and negative interpretation element entered interpersonal category that happen on five daughters in law who lived with her mother in law. While there were five factors that caused conflict in this research, they were lack of communication happen on three daughters in law. Second, egocentrism happen on three daughters in law. Then economy problem happen on one daughter in law, next different opinion happen on five daughters and last was misunderstanding happen on five daughters in law.
\end{abstract}

Keywords: Conflict; Daughter in Law; Mother in law; live in one house.

Dipublikasikan Oleh :

UPT Publikasi dan Pengelolaan Jurnal

Universitas Islam Kalimantan Muhammad Arsyad Al-Banjari Banjarmasin 


\section{PENDAHULUAN}

Manusia diciptakan Tuhan Yang Maha Esa untuk saling mencintai dan hidup berpasangpasangan. Semua orang butuh cinta, baik mencintai maupun untuk dicintai. Cinta tidak memandang usia, jenis kelamin dan status sosial. Jatuh cinta kepada lawan jenis adalah suatu hal yang alamiah, hal ini terjadi ketika orang mulai menginjak usia dewasa (Kinanti \& Hendrati, 2013). Salah satu tugas perkembangan orang dewasa adalah membina keluarga, sehingga mempunyai pasangan hidup menjadi penting yang kemudian diwujudkan dengan cara menikah. Pernikahan merupakan perjanjian, karena dari padanya lahir hak-hak dan kewajiban dari dan kepada setiap orang yang terkait didalamnya (suami, istri, anak yang lahir daripadanya) (Rahmah, Quraisy, \& Risfaisal, 2019).

Keluarga adalah tempat berlindung yang sangat aman dan nyaman bagi setiap orang, karena didalam keluargalah seseorang yang ada didalamnya termasuk suami, istri, dan anak seharusnya mendapatkan kesenangan, ketenangan, dan kasih sayang yang penuh. Sehingga dapatlah terwujud suatu peribahasa bahwa "Rumahku adalah Surgaku", yang pasti apabila rumah itu adalah surga, siapapun yang ada didalamnya pasti akan merasa betah karena tidak ada yang merasakan kesepian, kesendirian, ataupun kekurangan kasih sayang dan juga Terciptanya keluaraga yang baik pasti terjadi karena pernikahan yang baik pula (Fitroh, 2011). Sebaliknya jika usia pernikahan belum matang maka berpotensi konflik didalamnya salah satunya belum adanya kesiapan baik secara fisik (usia muda) dan psikis (Kabang, Trisnowati, \& S, 2018).

Pernikahan adalah amanah dan tanggungjawab bagi pasangan yang masingmasing mempunyai niat tulus untuk membangun mahligai kehidupan bersama dan menyadari bahwa pernikahan ialah tanggungjawab dan amanah, maka pernikahan mereka bisa menjadi surga. Apalagi bila keduanya saling mencintai (Jamal, 2017).

Terjadinya sebuah pernikahan tidak hanya melibatkan dua insan yang saling mencintai. Di waktu yang sama, pernikahan juga menyatukan dua keluarga yang sebelumnya saling tidak mengenal. Apabila sudah terjadi pernikahan, maka hendaklah suami menyayangi, menghormati keluarga istri, terutama orang tua istri demikian juga sebaliknya dengan istri hendaklah menyayangi, menghormati keluarga suami dan terutama orang tua suami/ mertua (Saputra, Hartati, \& Aviani, n.d.).

Mertua adalah orang tua yang harus dihormati, sebagaimana menghormati orang tua kandung sendiri (Mawadda, 2001: 22-24). Rasulullah SAW memberi pesan bahwa orang yang paling baik adalah orang yang memperlakukan keluarganya dengan baik. Salah satu contoh bentuk kebaikan kepada keluarga ialah seperti pada beberapa kondisi, keluarga muda memilih tinggal bersama orang tua, bukan dirumah kontrakan atau bahkan rumah sendiri. Sebagian memilih tinggal bersama mertua karena desakan orang tua atau sanak kerabat istri. Sebagian karena desakan ekonomi, sehingga lebih baik dana yang terbatas dialokasikan untuk kepentingan-kepentingan lain yang maslahat daripada membayar sewa rumah. Sebagian lagi karena dorongan untuk berbakti kepada orang tua (Ayu, 2017). Namun, ketika dihadapkan pada sebuah kondisi untuk tinggal bersama, ditemui dalam beberapa keadaan, konflik antara menantu perempuan dan ibu mertua menjadi permasalahan sehari-hari. Saat seorang memutuskan berada dalam kondisi tersebut maka seorang menantu diharuskan untuk dapat beradaptasi dengan lingkungan keluarga barunya tersebut dan mampu menghadapinya dengan baik (Mohammad, 2012 ).

Psikolog di Newnham College, Universitas Cambrigde Dr. Terri Apter dalam penelitiannya pada buku What Do You Want From $\mathrm{Me}$ ? melakukan wawancara terhadap pasangan dari berbagai negara dalam waktu hampir 20 tahun. Dari situ, dia mengungkapkan bahwa problem dengan mertua tidak hanya dialami oleh menantu perempuan, tapi juga lakilaki. Dr. Terri mengungkapkan, sebanyak $75 \%$ pasangan yang disurveinya, mengaku memiliki permasalahan hubungan dengan mertuanya. Bahkan, dari angka tersebut, sebanyak 15\% pasangan mengatakan kalau hubungan mereka dengan mertuanya berada di titik ketegangan. Menantu perempuan menjadi pihak yang paling banyak bermasalah dengan mertuanya. Dalam penelitiannya, Dr. Terri menyebutkan bahwa ada sebanyak $60 \%$ menantu perempuan yang memiliki permasalahan dengan mertuanya (Santi, 2015).

Berdasarkan penelitian yang dilakukan oleh Saputra di Bukittinggi menemukan bahwa mayoritas pasangan suami istri yang tinggal terpisah dari orang tua/mertua memiliki tingkat kepuasan pernikahan yang tinggi, dimana diketahui pasangan suami istri yang berada pada kepuasan pernikahan yang tinggi yaitu sejumlah 
29 orang $(96,67 \%)$. Sedangkan pasangan yang tinggal serumah dengan orang tua/mertua sejumlah 26 orang $(86,67 \%)$. Skor empiris pada pasangan suami istri yang tinggal terpisah dari orang tua juga mempunyai rata-rata lebih tinggi yaitu 162,96 dibandingkan dengan pasangan suami istri yang tinggal serumah dengan orang tua/mertua dengan rata-rata 152,06 . Penelitian John Gottman menunjukkan bahwa beberapa hal yang dapat menjadi masalah dalam perkawinan yang dapat menyebabkan perceraian adalah hubungan dengan mertua, keuangan, perkawinan, stres, pekerjaan rumah tangga, seks, dan bayi (Saputra, 2014 : 138).

Adapun penelitian dari Milda Rahmah Penyebab terjadinya konflik menantu yang tinggal serumah dengan mertua biasanya disebabkan oleh beberapa faktor yaitu mertua sering berkomentar, mertua sering ikut campur, mertua yang kerap membandingkan menantu dan menikah tanpa restu orang tua (Rahmah et al., 2019). Selain itu juga ada berbicara mengenai konflik pernikahan pada penelitian yang dilakukan oleh Eva Meizara Puspita Dewi dan Basti yang menyatakan bahwa konflik lebih tinggi dialami oleh Pasangan suami istri (pasutri) yang tinggal satu rumah dibandingkan dengan pasutri yang tinggal terpisah. Ada empat cara pasangan dalam menyelesaikan konfliknya diantaranya adalah menghindari konflik, mengalah, diskusi,dan kompetensi (Dewi, 2008:48-49).

Dari beberapa penelitian yang dilakukan sebelumnya lebih berfokus pada tingkat kepuasan antara menantu dan mertua yang tinggal serumah dengan yang tidak serumah sedangkan penelitian ini berfokus pada identifikasi konflik antara menantu dan mertua yang tinggal serumah. Penelitian mengenai identifikasi konflik antara menantu dan mertua yang tinggal serumah masih sangat sedikit, karena hal tersebut maka perlu kiranya menggali informasi mengenai identifikasi konflik yang dialami oleh menantu dan mertua yang tinggal serumah, khususnya yang ada di gang giat Palangka Raya, sehingga kedepannya tidak mengalami hal negatif yang dapat mempengaruhi kualitas hubungan antara menantu dan mertua yang tinggal serumah

\section{METODE}

Penelitian ini menggunakan pendekatan kualitatif dengan model fenomenologi, dimana semua data yang diambil berdasarkan perspektif emik.

\section{Sumber Data}

Menurut hasil wawancara kepada rukun tetangga di lokasi penelitian jumlah kepala keluarga yang ada di tempat penelitian yaitu untuk Gang Giat berjumlah 135 kepala keluarga dan 10 menantu yang tinggal serumah dengan mertuanya (RH, 28-01-2021), Sedangkan di Gang sari 45 berjumlah 55 kepala keluarga dan 5 menantu dan mertua yang tinggal serumah (AL, 28-01-2021) dan di Gang Sayur berjumlah 170 kepala keluarga dan 10 menantu yang tinggal serumah dengan mertua (SM, 28-01-2021). Adapun perekonomian masyarakat di daerah tersebut termasuk dalam golongan menengah kebawah. Teknik pengambilan data primer menggunakan teknik Purposive sampling, yang artinya data diambil dengan pertimbangan tertentu, yang sudah memiliki kriteria subjek terkait penelitian (wahyuni, n.d.). Berdasarkan hal tersebut, maka subjek penelitian berjumlah lima orang yaitu: NA, N, SN, FH dan TS yang tinggal serumah dengan mertuanya di Gang. Giat, Gang. Sayur dan Gang. Sari 45.

\section{Teknik Pengumpulan Data}

Teknik pengumpulan data yang digunakan dalam penelitian ini yaitu: dokumentasi, wawancara dan observasi. Observasi atau pengamatan merupakan suatu teknik atau cara mengumpulkan data dengan jalan mengadakan pengamatan terhadap kegiatan yang sedang berlangsung (Sudaryono, 2018). Sedangkan Wawancara yaitu pertemuan dua pihak untuk bertukar ide dan informasi melalui tanya jawab sehingga dapat dikonstruksikan makna dalam suatu data tertentu. Wawancara digunakan untuk memperoleh keterangan langsung dari subjek penelitian yang diharapkan mampu menjadi bahan acuan dalam menyelesaikan penelitian ini (Lexy, 2015). Adapun Dokumentasi adalah kegiatan pengumpulan data yang dilakukan melalui penelusuran dokumen. Teknik ini dilakukan dengan memanfaatkan dokumen-dokumen tertulis, gambar, foto, atau benda-benda lainnya yang berkaitan dengan aspek-aspek yang diteliti (Widodo, 2018).

\section{Teknik Analisis Data}

Untuk menganalisis data yang telah dihasilkan, maka dalam penelitian ini menggunakan metode dari Milles dan Huberman. Yakni dengan beberapa langah yaitu collecting, mendisplay data kemudian verifikasi data yang 
berujung pada langkah terakhir yaitu data conclution (Sugiyono, 2010).

Pengumpulan data dilakukan melalui sumber data dan selanjutnya melakukan reduksi data dimana memfilter data-data yang ada sesuai dengan pertanyaan penelitian yang telah dilakukan. Setelah melakukan reduksi data maka langkah selanjutnya melakukan penyajian data dimana adanya pengelompokkan data-data yang diinginkan dan disesuaikan dengan fokus penelitiannya. Dan langkah terakhir adalah verifikasi data atau menarik sebuah kesimpulan hasil dari analisis yang dibuat.

Data ini yang nantinya akan menjawab terhadap rumusan masalah tentang identifikasi konflik antara menantu dan mertua yang tinggal serumah di Kota Palangka Raya.

Sebelum proses analisa data dilakukan, data-data yang didapat di lapangan dinarasikan terlebih dahulu secara utuh dan sistematis. Kemudian dikategorikan sesuai topik untuk menjelaskan sumber data dalam penelitian ini, maka data yang sudah dipaparkan dianalisis menggunakan teori-teori yang berkaitan dengan penelitian mengenai konflik antara menantu dan mertua yang tinggal serumah di kota Palangka Raya.

\section{HASIL DAN PEMBAHASAN}

Berdasarkan data yang telah didapatkan dari hasil observasi, wawancara dan dokumentasi dengan indikator faktor-faktor konflik dan jenisjenis konflik terhadap menantu yang tinggal serumah dengan mertuanya adapun hasilnya ditemukan adanya konfik interpersonal dan intrapersonal, adapun yang masuk dalam kategori intrapersonal pada unsur pendekatanpenghindaran terjadi pada dua menantu yaitu $\mathrm{N}$ dan TS di buktikan dengan wawancara $\mathrm{N}$ dan TS sebagai berikut :

“...bepander kah, bediam kah sama ja, jadi Bediam ai aku sampai sidin kada ingat lagi kaitu ai (N)" dan “...Ya bediam ai aku kada jua ah bebahasan, mun orang tuha be ucap nih sidin tu pang dah yang paling bujur, Bediam ai aku nah sidin kena bisa ai kada ingat (TS)". Dari hasil wawancara tersebut dapat dikatakan bahwa menantu $\mathrm{N}$ dan TS masuk $\mathrm{k}$ edalam konflik intrapersonal dengan pendekatan-penghindaran dikarenakan diam atau bicaranya menantu selalu menimbulkan konflik. Sedangkan yang masuk dalam kategori unsur penghindaran-penghindaran terjadi pada tiga menantu yaiu NA, SN dan $\mathrm{FH}$ dapat dibuktikan dengan wawancara ketiga menantu sebagai berikut : “...Bediam ja pang, koler menyuarai kalo tehualkan jadi masalah pulang (NA)”, “...Mun aku nang salah aku am dahulu memanderi sidin sekira baik am. Ngalih mun serumah ni amun ada masalah kaitu (SN)", “...Di panderi ai sidin, tekana tu sidin menerima ja tapi wayah nya ada sidin nang kada mau kalah,jadi beranai ai, ya hasil nya tu mun sidin nerima syukur mun kada tu kada ai dah, kada kawa di karasi jua yang kaitu (FH)" Dari hasil wawancara tersebut dapat dikatakan bahwa menantu NA, FH dan SN masuk dalam kategori konflik intrapersonal penghindaran-penghindaran dikarenakan menantu NA lebih memilih diam ketika perbuatan mertuanya tidak dia sukai agar konflik tidak terjadi sedangkan menantu SN dan FH lebih memilih bicara agar konflik cepat terselesaikan, selanjutnya yang masuk pada katagori interpersonal pada unsur escalation, invalidation, withdrawal and avoidance dan negatife interpretation terjadi pada lima menantu yaitu NA, N, SN, FH dan TS yang tinggal serumah dengan mertuanya dapat dibuktikan dari salah satu hasil wawancara narasumber sebagai berikut : “...Aku pang nang memanderi sidin dulu, mun sidin pina ubah kan, di panderi ai begimitan, mun aku nang merasa meulah salah tapi amun sidin nang beulah salah aku bediam ai, sidin bediam jua (NA)“ Dari wawancara tersebut dapat dikatakan bahwa penyebab awal timbulnya masalah antara menantu NA, dan mertuanya disebabkan perilaku mertuanya yang apabila berbuat salah terkesan diam dan tidak ingin berinisiatif untuk menyelesaikan konflik hal ini pun sesuai dengan penjelasan escalation yang awal mula masalah itu diakibatkan salah satunya merespon dengan negatif. Setelah salah satu merespon negatif hal selanjutnya yang akan terjadi yaitu ada pola dimana salah satu secara langsung atau tidak langsung meremehkan pola pikir, perasaan dan karakter atau invalidation. Adapun salah satu hasil wawancara narasumber yang lain : "...Aku bediam ai, sidin ai yang rajin memadahi aku, Baik ja sidin kadang madahi aku, aku nya ai nah yang kaini, kda tapi measi (N)" Dari wawancara tersebut dapat dikatakan bahwa menantu $\mathrm{N}$ tidak memikirkan perasaan mertuanya di karenakan menantu $\mathrm{N}$ bersikap acuh terhadap terhadap nasehat mertuanya. Setelah salah satu secara langsung atau tidak langsung meremehkan pola pikir, perasaan dan karakter hal selanjutnya yang akan terjadi yaitu akan muncul pola di mana salah satunya akan menunjukkan keengganan atau tinggal dalam diskusi penting maksudnya salah satunya cenderung menghindar, diam atau terlalu cepat menerima saran (padahal tidak ada maksud untuk melakukan saran tersebut ketika berkonflik atau whithdrawal and avoidance. Adapun hasil 
Salman, Arini Safitri, Desi Erawati

Jurnal Bimbingan dan Konseling Ar-Rahman

Volume 7, Nomor 2, Tahun 2021

e-ISSN 2477-6300

wawancara dengan salah satu menantu sebagai berikut : "...Bediam ai aku sampai sidin kada ingat lagi kaitu ai, Bediam ai aku ding ai (N)" Dari hasil wawancara tersebut dapat dikatakan bahwa menantu $\mathrm{N}$ cenderung diam ketika berkonflik dikarenakan menantu $\mathrm{N}$ tidak memperdulikan hal itu. Setelah pola di mana salah satunya akan menunjukkan keengganan atau tinggal dalam diskusi penting maksudnya salah satunya cenderung menghindar, diam atau terlalu cepat menerima saran (padahal tidak ada maksud untuk melakukan saran tersebut) ketika berkonflik hal selanjutnya yang akan terjadi yaitu salah satunya secara konsisten percaya bahwa motif lain dari lawan berkonfliknya lebih negatif dari pada yang sesungguhnya terjadi maksudnya salah satunya akan selalu berprasangka buruk ketika pembicaraan atau perbuatan itu menurutnya akan memicu konflik atau negatife interpretation. Adapun hasil wawancara dengan salah satu menantu sebagai berikut : “...Duit tu pang iya kalo, ngaran nya dua laki bini ni kan handak ai jua kaya orang tu nah nukar ini itu, tapi ngaran nya sidin meliat di sambat sidin ai, "nukar-nukar kaitu kadada hasilnya, baik di tabung jar padahal nukar gasan dirumah jua (FH)" Dari wawancara tersebut dapat dikatakan bahwa mertua menantu FH percaya bahwa barang-barang yang di beli menantu FH itu hanya menghabiskan uang saja padahal itu untuk keperluan rumah. Sedangkan Faktor yang melatarbelakangi terjadinya konflik dalam penelitian ini ada lima yaitu, kurangnya komunikasi terlihat pada tiga menantu yaitu NA, $\mathrm{N}$ dan SN di buktikan dengan hasil wawancara salah satu narasumber yaitu : "...Jarang ding ai soal nya aku ni jarang kalo dirumah (N)" . Kemudian yang kedua, sikap egosentrisme dalam hal ini ditemukan juga pada tiga menantu yaitu $\mathrm{N}$, FH dan TS dapat dilihat dari salah satu hasil wawancara dengan narasumber, sebagai berikut : “...Bepander ja jarang apa lagi kaitu, Mun dari aku banyak pang nah, aku kurang perhatian kesidin, macam-macam ai (N)" . selanjutnya masalah ekonomi yang dialami oleh satu menantu yaitu $\mathrm{N}$ adapun hasil wawancaranya ialah : "...Besar banar, rumah umpat sidin, makan kadang umpat sidin jua, laki gin begawi masih umpat sidin jua kadang-kadang (N)" . Berikutnya adanya perbedaan pendapat ditemukan pada kelima menantu yang di buktikan dari hasil salah satu wawancara dari narasumber sebagai berikut : “...Ya bediam ai aku kada jua ah bebahasan, mun orang tuha be ucap nih sidin tu pang dah yang paling bujur (TS)" dan yang terakhir yaitu, salah paham hal ini juga dimiliki oleh kelima menantu yaitu NA, N, SN, FH dan TS Dibuktikan dengan salah satu hasil wawancara dengan narasumber yaitu : “...Masalah anak biasanya ni ding ai, kam tahu ja lo ding kanakan wayah ni mun kada hp diudak main game iya kalo (SN)" .

Dalam berumah tangga terjadinya konflik di dalam keluarga bukanlah hal yang tidak biasa lagi, apalagi konflik antara menantu dengan mertua yang tinggal serumah. Bagaimana konflik ini terjadi dirasakan oleh kelima menantu yang tinggal serumah dengan mertuanya, yaitu : NA, N, SN, FH dan TS, adapun proses konflik yang mereka alami itu dimulai dengan adanya konflik interpersonal dan konflik intrapersonal. Terjadinya konflik intrerpersonal dibagi menjadi empat aspek, yaitu : 1. Escalation 2. Invalidation 3. Withrawal and Avoidance 4. Negative Interpretation. Sedangkan konflik intrapersonal menurut James and Charles Wankel dibagi menjadi 3 aspek, yaitu : 1. Pendekatanpendekatan 2. Pendekatan-penghindaran 3 . Penghindaran-penghindaran.

\section{Konfik Intrapersonal}

Hunt and Metcalf (1996) mengemukakan Konflik intrapersonal adalah konflik yang terjadi dalam diri individu sendiri, misalnya ketika keyakinan yang dipegang individu bertentangan dengan nilai budaya masyarakat, atau keinginannya tidak sesuai dengan kemampuannya. Konflik intrapersonal ini bersifat psikologis, yang jika tidak mampu diatasi dengan baik dapat menggangu bagi kesehatan psikologis atau kesehatan mental (mental hygiene) individu yang bersangkutan. Ada tiga macam bentuk konflik intrapersonal Menurut James A.F. Stoner dan Charles Wankel yaitu Pendekatanpendekatan ialah dimana seorang dihadapkan oleh dua hal yang dianggapnya sama-sama menarik atau memiliki nilai positif. Pendekatanpenghindaran ialah dimana seseorang dihadapkan oleh dua hal yang dianggapnya sama-sama menyulitkan atau memiliki nilai negatif. Penghindaran-penghindaran ialah dimana seseorang dihadapkan oleh satu hal yang memiliki nilai positif dan negatif sekaligus (Muspawi, 2014.).

Berdasarkan dari hasil wawancara dapat dikatakan bahwa dua menantu yang diam atau bicaranya selalu menimbulkan konflik. Hal ini sejalan dengan apa yang disampaikan oleh James A.F dan Charles Wankel tentang konflik intrapersonal pendekatan-penghindaran mereka

Dipublikasikan Oleh :

UPT Publikasi dan Pengelolaan Jurnal

Universitas Islam Kalimantan Muhammad Arsyad Al-Banjari Banjarmasin 
mengatakan bahwa ketika seseorang dihadapkan dengan dua hal yang pilihan nya sama-sama memiliki resiko besar seperti menantu yang apabila diam atau bicara saat berbeda pendapat selalu salah dimata mertuanya. Hasil wawancara tersebut juga sesuai dengan pendapat Kurt Levin dalam (karmiah, 2009) menyebutkan keadaan seseorang yang berada pada suatu keadaan dimana ia dihadapkan dua situasi, yang keduaduanya memiliki nilai negatif yaitu diam dan bicara nya menantu selalu menimbulkan konflik. Sedangkan diketahui dari hasil wawancara dapat dikatakan bahwa menantu lebih memilih diam ketika perbuatan mertuanya tidak dia sukai agar konflik tidak terjadi sedangkan dua menantu lebih memilih bicara agar konflik cepat terselesaikan. Hal ini sejalan dengan apa yang disampaikan oleh James A.F dan Charles Wankel tentang konflik intrapersonal penghindaran-penghindaran yaitu ketika seseorang dihadapkan dengan satu hal yang mempunyai nilai positif dan nilai negatif seperti menantu yang memilih diam ketika perbuatan mertuanya tidak dia sukai agar konflik tidak terjadi, walaupun ketika diam perasaan kesal muncul saat melihat mertua melakukan hal yang tidak disukai, akan tetapi dengan diam konflik bisa terhindarkan.

\section{Konflik Interpersonal}

Menurut Hunt and Metcalf (1996)

konflik interpersonal ialah konflik yang terjadi antar individu. Konflik ini terjadi dalam setiap lingkungan sosial, seperti dalam keluarga, kelompok teman sebaya, sekolah, masyarakat dan negara. Markman, Stanley dan Blumberg mengungkapkan 4 aspek konflik interpersonal, yaitu : Escalation Terjadi saat salah satunya merespon negatif satu sama lain sehingga kondisi menjadi semakin buruk dan lebih buruk. Seringkali, komentar negatif meningkatkan kemarahan dan frustrasi. Hal ini tidak hanya meningkatkan intensitas emosi yang dapat menciptakan masalah, komentar negatif ini cenderung berubah dari kemarahan sederhana menjadi komentar yang menyakitkan tentang satu sama lain. Invalidation adalah pola dimana salah satu secara langsung atau tidak langsung meremehkan pola pikir, perasaan, dan karakter pasangannya.Withdrawal and Avoidance Adalah akan muncul pola di mana salah satunya akan menunjukkan keengganan atau tinggal dalam diskusi penting maksudnya salah satunya cenderung menghindar, diam atau terlalu cepat menerima saran (padahal tidak ada maksud untuk melakukan saran tersebut) ketika berkonflik.
Negative Interpretation Ialah salah satunya secara konsisten percaya bahwa motif lain dari lawan berkonfliknya lebih negatif dari pada yang sesungguhnya terjadi maksudnya salah satunya akan selalu berprasangka buruk ketika pembicaraan atau perbuatan itu menurutnya akan memicu konflik (Puspitasari, 2018).

Berdasarkan serangkaian jawaban menantu yang tinggal serumah dengan mertuanya, terlihat dari hasil wawancara menantu dengan mertua yang tingga serumah awal mula terjadinya konflik interpersonal dengan mertuanya disebabkan mertuanya berbuat salah maka aksi diam dan tidak ingin berinisiatif untuk menyelesaikan konflik, mengabaikan nasehat atau teguran dari mertua dan menantu jadi pelampiasan emosi dari mertua. Hal ini sesuai dengan pendapat Markman, Stanley dan Blumberg (2010). Bahwa awal mula konflik interpersonal itu terjadi dikarenakan adanya Escalation yaitu salah satu pihak merespon negatif sehingga membuat kondisi semakin buruk dan lebih buruk lagi. Hasil wawancara tersebut juga sesuai dengan pendapat Luthans yaitu, Antecedent Conditions or latent Conflict yang merupakan kondisi yang berpotensi untuk menyebabkan, atau mengawali sebuah episode konflik (Muspawi, n.d.).

Diketahui dari hasil wawancara menantu dengan mertua yang tinggal serumah dapat diketahui bahwa menantu mengabaikan pola pikir mertuanya, menantu tidak memikirkan perasaan mertuanya dan apabia sedang berbeda pendapat mertua seau merasa benar. Hal ini sesuai dengan yang dikatakan oleh Markman, Stanley dan Blumberg (2010) mereka mengatakan setelah terjadi nya Escalation hal yang terjadi selanjutnya adalah Invalidation yaitu dimana salah satunya secara langsung atau tidak langsung meremehkan pola pikir, perasaan dan karakternya.

Diketahui dari hasil wawancara antara menantu dengan mertua yang tingga serumah, mendapatkan hasil bahwa menantu cenderung tidak berkeinginan untuk melakukan saran dari mertuanya, menantu yang cenderung diam dan tidak peduli ketika berkonflik dan mertua yang selalu salah paham dengan hal yang sama menyebabkan menantu menghindar. Hal ini pun sejalan dengan apa yang di sampaikan oleh Markman, Stanley dan Blumberg (2010) mereka mengatakan setelah terjadi nya Invalidation hal yang akan selanjutnya terjadi adalah Withdrawal and Avoidance yaitu pola di mana salah satunya akan menunjukkan keengganan atau tinggal dalam diskusi penting maksudnya salah satunya 
Salman, Arini Safitri, Desi Erawati

Jurnal Bimbingan dan Konseling Ar-Rahman

Volume 7, Nomor 2, Tahun 2021

e-ISSN 2477-6300

cenderung menghindar, diam atau terlalu cepat menerima saran (padahal tidak ada maksud untuk melakukan saran tersebut) ketika berkonflik.

Dilihat dari hasil wawancara dengan menantu yang tinggal serumah dengan mertua dapat dijelaskan bahwa mertua percaya bahwa menantu selalu bekerja padahal menantu sering beristirahat apabila merasa lelah. Sedangkan dari hasil wawancara yang berbeda dapat dikatakan bahwa mertua percaya bahwa menantu adalah orang yang boros dikarenakan menantu tidak menjelaskan kemana uang sehari-hari itu habis hal itu pun sejalan dengan hasil wawancara dengan informan yaitu tetangganya mengatakan bahwa menantu boros dan jarang sekali dirumah. Begitu pula menantu lainnya, mertuanya percaya bahwa barang-barang yang di belinya itu hanya menghabiskan uang saja padahal itu untuk keperluan rumah hal itu juga sama seperti yang disampaikan tetangganya bahwa $\mathrm{FH}$ pernah menceritakan hal itu juga. Lain halnya dengan dari hasil wawancara lainya bahwa mertua percaya bahwa apabila anak dari menantu sedang memainkan gawai maka mertuanya mengira sedang bermain dan tidak belajar padahal sekolah dimasa pandemi ini memang menggunakan gawai, mertua mengira menantu tidak mendidik anaknya dengan baik dengan membiarkan anak selalu bermain gawai. Hal ini pun sejalan dengan hasil wawancara dengan tetangganya bahwa masalah yang terjadi antara menantu dan mertuanya didalam ruang lingkup yang sama yaitu, pola asuh anak. Berbeda dengan menantu ini, dari hasil wawancara dapat dikatakan menantu percaya bahwa pendapat mertuanya akan selalu menimbulkan konflik nyatanya tidak semuanya seperti itu. Hal ini pun sejalan dengan apa yang di sampaikan oleh Markman, Stanley dan Blumberg (2010) mereka mengatakan setelah terjadi nya Withdrawal and Avoidance maka hal selanjutnya yang akan terjadi adalah Negative Interpretation yaitu salah satunya secara konsisten percaya bahwa motif lain dari lawan berkonfliknya lebih negatif dari pada yang sesungguhnya terjadi maksudnya salah satunya akan selalu berprasangka buruk ketika pembicaraan atau perbuatan itu menurutnya akan memicu konflik.

\section{Faktor Timbulnya Konflik}

Menurut Sofyan wills (2005) terdapat beberapa faktor yang menyebabkan munculnya konflik, yaitu: Kurangnya komunikasi, komunikasi merupakan suatu hal penting yang harus dijaga dalam hubungan, dengan komunikasi yang baik dapat mempererat hubungan antar satu sama lain, terhindar dari kesalahpahaman, sebaliknya jika komunikasi tidak dijalin dengan baik maka akan memberikan dampak negatif pada hubungan seperti adanya jarak antar satu sama lain. Sikap egosentrisme adalah kondisi dimana individu merasa orang lain tidak penting dan selalu mengutamakan dirinya sendiri dibandingkan dengan hal lain, serta selalu melakukan banyak cara agar mendapatkan perhatian. Akibat dari sifat ini orang lain cenderung menghindar darinya dan dapat membuat seseorang merasa tersinggung. Masalah ekonomi, pada dasarnya kebutuhan hidup menuntut setiap individu untuk memiliki penghasilan sehingga mencukupi berbagai kebutuhan dan tidak jarang masalah ekonomi menjadi penyebab terjadinya konflik karena tidak terpenuhinya kebutuhan tersebut (Agatha, 2019). Perbedaan pendapat Adalah suatu kondisi dimana masing-masing individu merasa yang paling benar, perbedaan pendapat mengakibatkan suasana menjadi tegang sehingga merasa tidak enak karena hal tersebutlah konflik bisa terjadi. Yang terakhir Salah paham, Konflik tidak jarang bersumber dari kesalahpahaman salah satu pihak atau kedua belah pihak. Misalnya seseorang memiliki tujuan baik tetapi pihak lain menganggap bahwa tujuan baik orang tersebut adalah tindakan yang merugikan sehingga menimbulkan rasa kurang enak, kurang simpati, dan justru kebencian (Maulana,2015).

Dilihat dari hasil wawancara dapat dikatakan bahwa menantu jarang berkomunikasi dengan mertuanya disebabkan menantu bekerja, jarang dirumah dan tidak adanya topik. Menurut Sofyan Wills (2005) kurangnya berkomunikasi dapat memicu timbulnya konflik. Jika komukasi tidak dijalin dengan baik maka akan memberikan dampak negatif pada hubungan seperti adanya jarak antar satu sama lain.

Diketahui dari hasil wawancara menantu yang tinggal serumah dengan mertuanya dapat diketahui bahwa menantu memiliki sikap egosentrisme dikarenakan menantu tidak memikirkan mertuanya dan apabila menantu melihat perlakuan mertuanya yang tidak ia sukai maka menantu akan menegur dan menyuruh mertua nya memperbaiki sikap nya. Hal ini sesuai dengan teori Sofyan Wills (2005) tentang sikap egosentrisme yaitu, merasa orang lain tidak penting dan selalu mengutamakan dirinya sendiri dibandingkan dengan hal lain.

Dari jawaban menantu yang tinggal serumah dengan mertuanya, hanya satu menantu

Dipublikasikan Oleh : 
yang memiliki masalah ekonomi dikarenakan suaminya masih bergantung kepada mertuanya dan juga tidak memiliki pengelolan ekonomi yang bagus sehingga penghasilan tidak sesuai kebutuhan. Dalam hasil wawancara tersebut juga didapatkan bahwa penyebab kesalahpahaman mertua juga disebabkan oleh masalah ekonomi menantu dan suaminya. Hal ini sesuai dengan teori Sofyan Wills (2005) tentang masalah ekonomi ia menyatakan tidak jarang masalah ekonomi menjadi penyebab terjadinya konflik karena tidak terpenuhinya kebutuhan tersebut. Hal tersebut juga sesuai dengan pendapat Setiawan (2007) tentang faktor-faktor yang menyebabkan rusaknya hubungan mertua dan menantu tentang ketidakmandirian anak setelah menikah Setiawan menyebutkan bahwa dalam hal ini banyak pasangan menikah tetapi masih tinggal di rumah orang tuanya. Secara finansial mereka belum mandiri. Dengan adanya campur tangan ini, maka tidak salah apabila orang tua masih mencampuri urusan rumah tangga anaknya (Suciati \& Sofyan, 2020).

Dilihat dari hasil paparan wawancara menantu yang tinggal serumah dengan mertuanya dapat dikatakan bahwa faktor penyebab konflik menantu dengan mertua ialah perbedaan pendapat, akan tetapi konflik itu terjadi apabila saat mertua merasa saat pendapatnya merasa lebih baik, mertua yang selalu merasa benar saat berbeda pendapat dan menantu yang lebih memilih diam dan tidak menghiraukan hal tersebut. Hal ini sesuai dengan teori Sofyan Wills (2005) tentang perbedaan pendapat yaitu adalah suatu kondisi dimana masing-masing individu merasa yang paling benar, perbedaan pendapat mengakibatkan suasana menjadi tegang sehingga merasa tidak enak karena hal tersebutlah konflik bisa terjadi.

Diketahui dari serangkaian jawaban menantu yang tinggal serumah dengan mertuanya dapat dikatakan bahwa penyebab timbulnya kesalahpahaman tersebut adalah masalah pekerjaan, keuangan dan pola asuh anak. Hal ini sesuai dengan teori Sofyan Wills (2005) tentang salah paham yaitu tidak jarang bersumber dari kesalahpahaman salah satu pihak atau kedua belah pihak. Misalnya seseorang memiliki tujuan baik tetapi pihak lain menganggap bahwa tujuan baik orang tersebut adalah tindakan yang merugikan sehingga menimbulkan rasa kurang enak, kurang simpati, dan justru kebencian. Hal ini juga sesuai Soerjono Soekanto (2013) menyebutkan penyebab konflik juga dikarenakan masalah ekonomi, pekerjaan, latar pendidikan dan pola asuh anak(Milda, 2018). Berbicara tentang konflik maka perlu mengidentifikasi faktorfaktor terjadinya konflik tersebut terlihat pada gamabr 1 tentang faktor terjadinya konflik sebagai berikut:

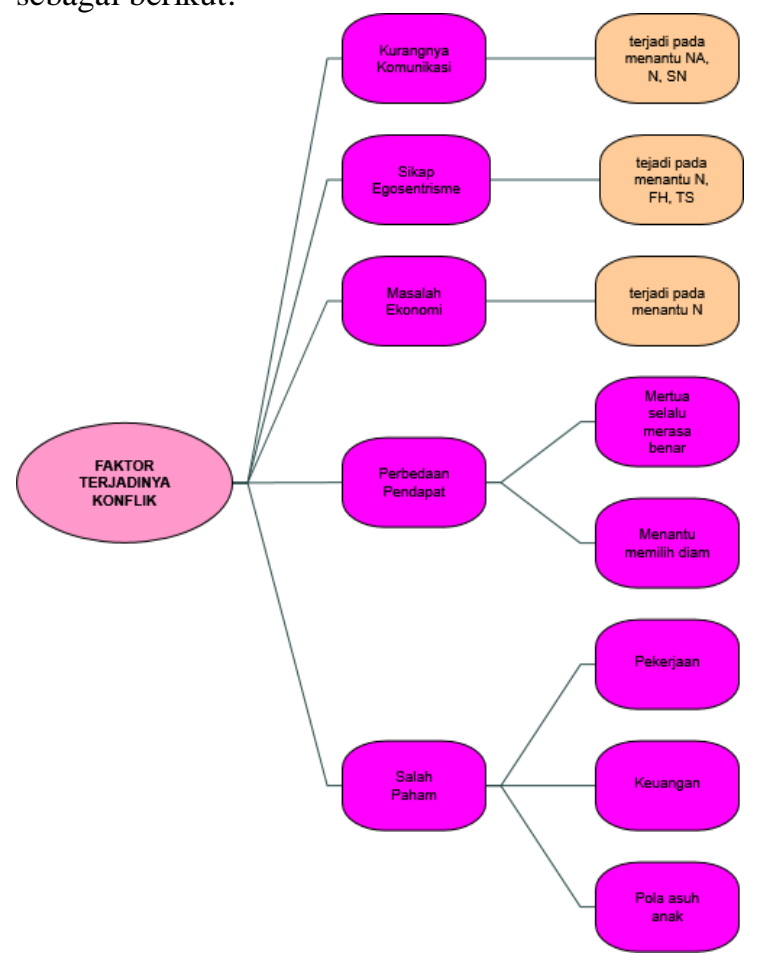

Gambar 1. Faktor Terjadinya Konflik

\section{PENUTUP}

Dikatakan bahwa konflik yang terjadi antara menantu dengan mertua yang tinggah serumah, ditemukan adanya konfik interpersonal dan intrapersonal. Dapat teridentifikasi dalam beberapa kategori yaitu kategori intrapersonal pada unsur pendekatan-penghindaran terjadi pada dua menantu sedangkan yang masuk dalam kategori unsur penghindaran-penghindaran terjadi pada tiga menantu, selanjutnya yang masuk pada katagori interpersonal pada unsur escalation, invalidation, withdrawal and avoidance dan negatife interpretation terjadi pada lima menantu yang tinggal serumah dengan mertuanya. Sedangkan faktor yang melatarbelakangi terjadinya konflik dalam penelitian ini ada lima yaitu, kurangnya komunikasi terlihat pada tiga menantu. Kemudian yang kedua, sikap egosentrisme dalam hal ini ditemukan juga pada tiga menantu. selanjutnya masalah ekonomi yang dialami oleh satu menantu. Berikutnya adanya perbedaan pendapat ditemukan pada kelima menantu dan yang terakhir yaitu, salah paham hal ini juga dimiliki oleh kelima menantu. 
Salman, Arini Safitri, Desi Erawati

Jurnal Bimbingan dan Konseling Ar-Rahman

Volume 7, Nomor 2, Tahun 2021

e-ISSN 2477-6300

Hasil penelitian ini masih dalam bentuk identifikasi konflik antara menantu dan mertua yang tinggal satu rumah dengan karakteristik keluarga kondisi perekonomian dan pendidikan kalangan menengah ke bawah.

\section{REFERENSI}

Al-Mawaddah. (2001). Dilema Antara Menantu dan mertua. Jawa Timur : Pustaka AlFurqon.

Ayu, D. A. P. (2017). Hubungan Self-Efficacy Dengan Resolusi Konflik Menantu Perempuan Yang Tinggal Serumah Dengan Mertua Perempuan (Undergraduate, University of Muhammadiyah Malang). University of Muhammadiyah Malang. Retrieved from http://eprints.umm.ac.id/43592/

Dewi, E. M. P. (2008). Konflik Perkawinan Dan Model Penyelesaian Konflik Pada Pasangan Suami Istri. 2(1), 10.

Fitroh, S. F. (2011). Hubungan Antara Kematangan Emosi Dan Hardiness Dengan Penyesuaian Diri Menantu Perempuan Yang Tinggal Di Rumah Ibu Mertua. Psikoislamika: Jurnal Psikologi Dan Psikologi Islam, 8(1). https://doi.org/10.18860/psi.v0i1.1547

Jamal, R. (2017). Resolusi Konflik Perkawinan Melalui Mediasi Dalam Perkara Perceraian Di Pengadilan Agama Manado. Jurnal Ilmiah Al-Syir'ah, 15(2). https://doi.org/10.30984/as.v15i2.478

Kabang, M., Trisnowati, E., \& S, T. M. R. (2018). Pemahaman Tentang Akibat Pernikahan di Bawah Umur Melalui Layanan Informasi Dengan Teknik DIiskusi. Jurnal Bimbingan Dan Konseling Ar-Rahman, 4(2), 55-60. https://doi.org/10.31602/jbkr.v4i2.1504

karmiah, diyana. (2009). Komunikasi Dalam Mengatasi Koonflik Rumah Tangga Di Kel. Sukarami Kec. Sukarami Kota Palembang (Skripsi). IAIN Raden Fatah, Palembang.

Kinanti, J. A., \& Hendrati, F. (2013). Hubungan Tipe Kepribadian Dengan Komunikasi Interpersonal Menantu Perempuan Terhadap Ibu Mertua. Jurnal Psikologi Tabularasa, 8(2). Retrieved from http://jurnal.unmer.ac.id/index.php/jpt/art icle/view/210

Muspawi, M. (n.d.). Manajemen Konflik ( Upaya Penyelesaian Konflik Dalam Organisasi ). 6 .

Dipublikasikan Oleh :

UPT Publikasi dan Pengelolaan Jurnal

Universitas Islam Kalimantan Muhammad Arsyad Al-Banjari Banjarmasin
Puspitasari, K. N. (2018). Hubungan Antara Tipe Kepribadian Big Five Dengan Konflik Interpersonal Dalam Organisasi Pada Karyawan di PT XX(Skripsi, Universitas Mercu Buana Yogyakarta). Universitas Mercu Buana Yogyakarta. Retrieved from http://eprints.mercubuanayogya.ac.id/2372/

Rahmah, M., Quraisy, H., \& Risfaisal, R. (2019). Konflik Sosial Menantu Yang Tinggal Serumah Dengan Mertua (Studi Kasus Di Desa Lempang Kecamatan Tanete Riaja Kabupaten Barru). Equilibrium: Jurnal Pendidikan, 7(2), 206-210. https://doi.org/10.26618/equilibrium.v7i2 .2626

Santi, Y. (2015). Peran Komunikasi Interpersonal Dalam Menjaga Hubungan Yang Harmonis Antara Mertua dan Menantu Perempuan. Jisip : Jurnal Ilmu Sosial Dan Ilmu Politik, 4(3). https://doi.org/10.33366/jisip.v4i3.128

Saputra, F., Hartati, N., \& Aviani, Y. I. (n.d.). Perbedaan Kepuasan Pernikahan Antara Pasuttri Yang Serumah dan Terpisah Dari Orangtua/Mertua. 10.

Suciati, S., \& Sofyan, N. (2020). Mewujudkan Keluarga Harmonis Melalui Pengelolaan Konflik Mertua Dan Menantu. Prosiding Seminar Nasional Program Pengabdian Masyarakat. https://doi.org/10.18196/ppm.37.265

Wahyuni, P. (n.d.). Kedudukan Cucu Sebagi Ahli Waris Pengganti Menurut Hukum Kewarisan Islam - Diponegoro University | Institutional Repository (UNDIP-IR). Retrieved 9 June 2021, from http://eprints.undip.ac.id/15075/

W,.J.S. Poerwadamita, W,.J.S. (1997). Kamus Umum Bahasa Indonesia. Jakarta : Balai Pustaka

Widodo. (2018). Metodologi Penelitian Populer \& Praktis. Depok: PT. RajaGrafindo Persada.

Zuriah, Nurul. (2006). Metodologi Penelitian: Sosial dan Pendidikan, Jakarta: PT. Bumi Aksara. Cet. ke-I. 